Article

\title{
Response of the Invasive Grass Imperata cylindrica to Disturbance in the Southeastern Forests, USA
}

\author{
Eric J. Holzmueller ${ }^{1, *}$ and Shibu Jose ${ }^{2}$ \\ 1 Department of Forestry, Center for Ecology, 1205 Lincoln Drive-MC 4411, Southern Illinois \\ University, Carbondale, IL 62901, USA \\ 2 Center for Agroforestry, School of Natural Resources, 203 ABNR, University of Missouri, \\ Columbia, MO 65201, USA; E-Mail: joses@missouri.edu \\ * Author to whom correspondence should be addressed; E-Mail: eholzmue@siu.edu; \\ Tel.: +1-618-453-3708; Fax: +1-618-453-7475.
}

Received: 29 June 2012; in revised form: 14 September 2012 / Accepted: 17 September 2012 / Published: 26 September 2012

\begin{abstract}
Imperata cylindrica is an invasive plant species that threatens diversity and forest productivity in southeastern ecosystems. We examined the effects of disturbance events, particularly fire and hurricane/salvage harvesting, to determine the effects on I. cylindrica abundance in longleaf pine (Pinus palustris) forests in the Florida panhandle. Areas that were burned or had greater biomass removal following a hurricane had a greater number of I. cylindrica patches and larger patch size. These results highlight the importance of disturbance events on expanding invasive species populations in this region and are likely applicable for other invasive species as well. Monitoring and treatment should follow disturbance events to ensure that invasive species populations do not exceed unmanageable levels.
\end{abstract}

Keywords: Imperata cylindrica; fire; hurricane; salvage logging

\section{Introduction}

Imperata cylindrica (L.) Beauv. (cogongrass) is an aggressive, $\mathrm{C}_{4}$ perennial grass that has invaded nearly 500,000 ha in the southeastern United States [1]. Native to Asia, the species was introduced to the United States multiple times, both accidently and intentionally, in the first part of the 20th 
century [2]. The species performs well on droughty, nutrient poor soils and it was initially intended as a forage crop, but high silica content when the plant matures makes it unpalatable to livestock [2,3]. It was also used for soil stabilization along road banks and mined lands, but unintended spread into adjacent areas led to placement of the species on the Federal noxious weed list and it is now considered one of the worst weeds in the world [4]. The grass can decrease native species plant biodiversity [5] and alter nutrient availability [6,7]. Imperata cylindrica is a problem particularly in young pine plantations in the southeastern United States. In a study of survival, growth and productivity of Pinus taeda L. (loblolly pine) seedlings established in a cutover area infested with I. cylindrica, Daneshgar et al. [8] reported a 35\% reduction in survival and a $63 \%$ reduction in height of $P$. taeda seedings 27 months after establishment in plots where I. cylindrica was allowed to persist.

Imperata cylindrica spreads both vegetatively and via seeds making it difficult to control. Typically, long distance dispersal is attributed to seed, and once established, patches expand primarily though rhizomes $[9,10]$. However, long-distance spread is also believed to occur via rhizomes though transportation of equipment and machinery and regeneration with rhizomes can occur from less than $0.1 \mathrm{~g}$ of material, which is smaller than a grain of rice [11]. There are several hypotheses as to what makes it so invasive, including that it has few natural enemies in invaded areas, that it is a successful competitor for nutrients, and its ability to produce allelopathic chemicals (phytotoxic compounds) [12].

In natural settings, it is believed that I. cylindrica first becomes established along roads and trails $[13,14]$. In addition, the species has the ability to become established in small forest gaps and a low light compensation point allows it to persist as small patches in shaded forest understories $[10,15]$. Several studies indicate that fire increases the abundance and dominance of I. cylindrica in forested areas, even in fire-dependent ecosystems. For example, both Lippincott [16] and Yager [17] reported increased abundance of I. cylindrica following burning in southern pine ecosystems in the southeastern United States. However, these studies have only tested the relationship between I. cylindrica and fire at the plot level. The objective of this study was to investigate the effects of disturbance, both fire and overstory removal, on a larger landscape level by using Geographic Information Systems (GIS) data to explore the relationship between I. cylindrica populations and disturbance. Based on the results from previous studies, we hypothesize that I. cylindrica will be more abundant in burned areas and areas where overstory was removed.

\section{Experimental Section}

Blackwater River State Forest (BRSF) encompasses approximately 84,000 ha in the Florida panhandle (Figure 1). It is adjacent to Conecuh National Forest and Eglin Air Force Base, making it part of one of the largest contiguous areas of longleaf pine/wiregrass ecosystem in the world. This system, which once dominated the southeastern United States, has been reduced to less than $95 \%$ of its original area. Due to this reduction, many of the species of flora and fauna found within the longleaf pine/wiregrass ecosystem are classified as endangered or threatened. In BRSF, upland areas are dominated by a Pinus palustris (longleaf pine), P. elliottii (slash pine), and Quercus (oak) species overstory, and a Gentiana pennelliana (wiregrass)-Serenoa repens (saw palmetto) understory. Bottomland areas are dominated by hardwood species such as Quercus nigra (water oak), Magnolia virginiana (sweetbay) and Cyrillara cemiflora (titi). Mean annual temperature is $19.2{ }^{\circ} \mathrm{C}$ 
and mean annual precipitation is $168 \mathrm{~cm}$. Elevation throughout BRSF ranges from $3 \mathrm{~m}$ to $88 \mathrm{~m}$ and soils are primarily comprised of loamy to fine-loamy ultisols.

Figure 1. Map depicting Blackwater River State Forest and location within the Florida panhandle.

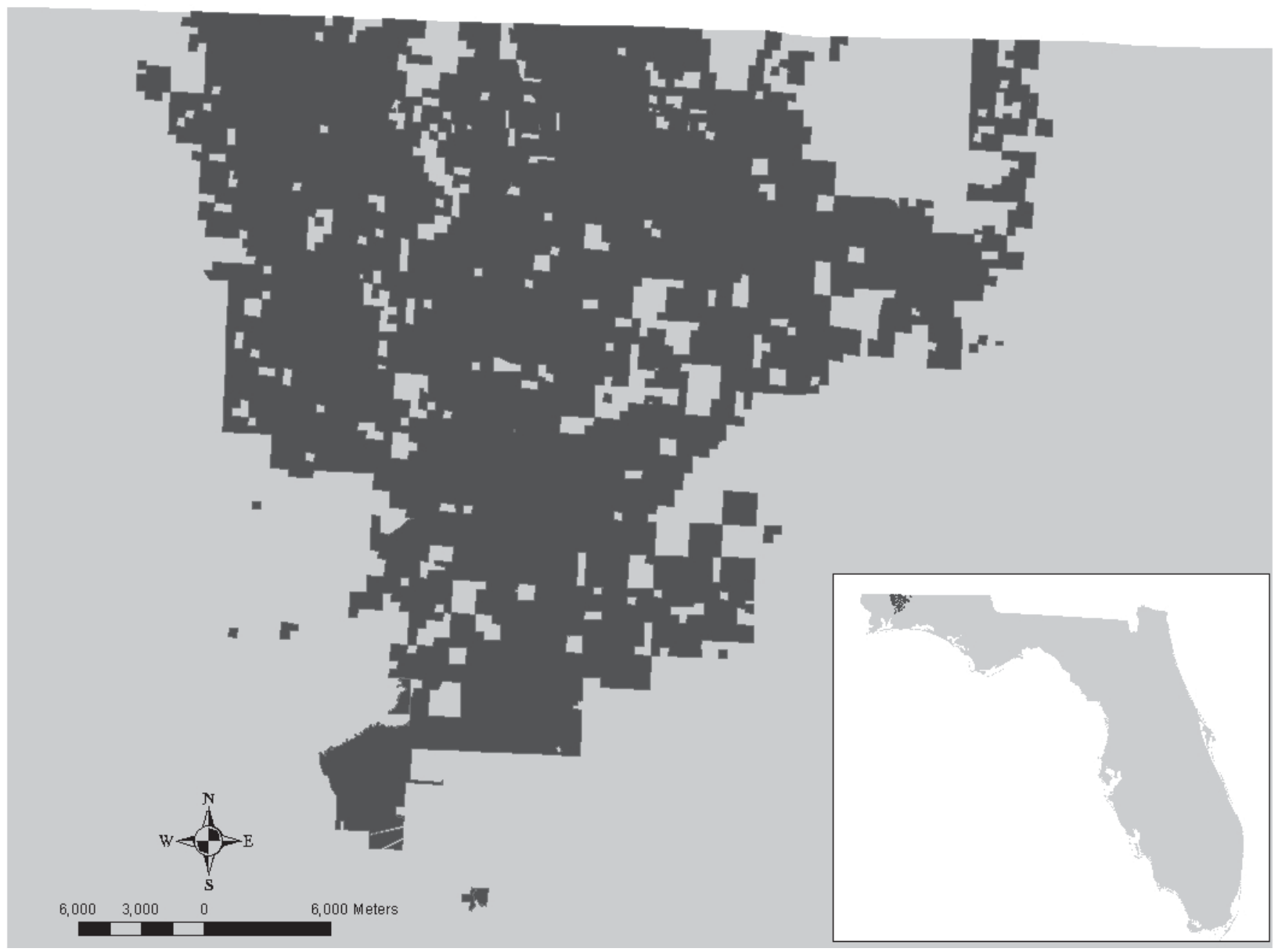

We used BRSF records to determine disturbance and I. cylindrica abundance within the area. Between 1983 and 2007 there were 60,161 ha (71\% of total area) burned in BRSF (Figure 2). Approximately $67 \%$ (40,126 ha) of the burned area had only burned once, while $33 \%(20,035$ ha) of the burned area had burned two or more times. Two hurricanes, Ivan and Dennis, caused considerable damage to BRSF in 2004 and 2005, respectively (Figure 3A). Salvage harvesting was conducted following hurricane Ivan in 2005 to remove downed or damaged wood and ranged from approximately 4500-9000 kg ha ${ }^{-1}$ (Figure 3B,C). Patches of I. cylindrica have been marked throughout BRSF. Each known patch of the invasive grass has a GPS location that gives UTM coordinates and the patch size. Overall, there 384 known patches of I. cylindrica that cover 30 ha within BRSF (Figure 4). We conducted an overlay analysis to determine the relationship between burning, hurricane/overstory removal, and I. cylindrica abundance within BRSF. Using this data we determined patterns of invasion based on burn frequency and biomass removal. 
Figure 2. Location of burned and unburned areas within Blackwater River State Forest.

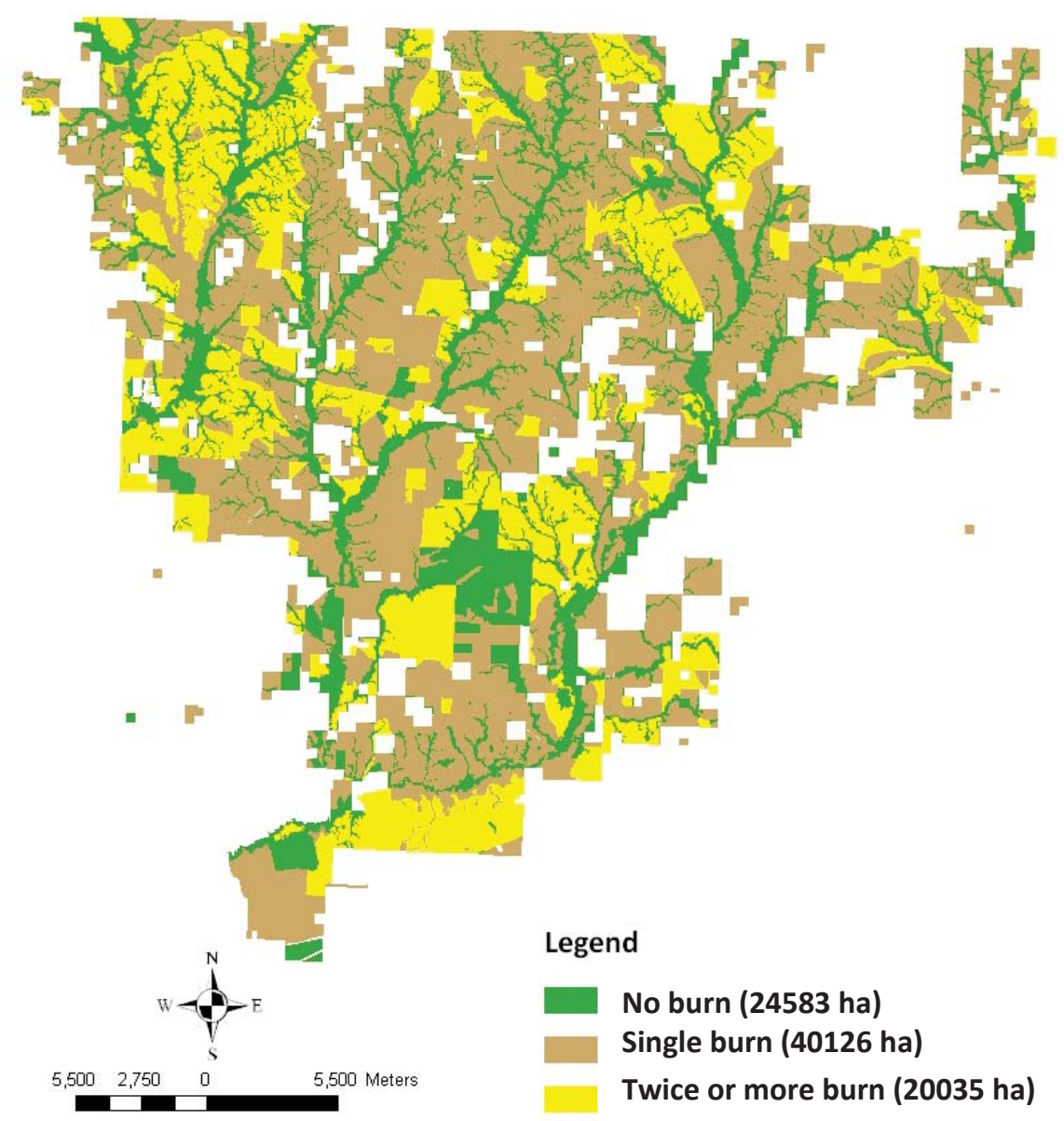

\section{Results and Discussion}

Most of the areas within BRSF infested with I. cylindrica are within burned areas, as compared to unburned areas ( $87 \%$ versus $13 \%$, respectively). Fifty three I. cylindrica patches covering 4 ha are in unburned areas, $228 \mathrm{I}$. cylindrica patches covering 17 ha are in single burn areas, and 103 patches covering 9 ha are in areas that had burned two times or more in BRSF. After calculating \% invasion $(\%$ invasion $=$ infested area of burn class/total area of burn class), we determined I. cylindrica was more than twice as likely to occur in burned areas compared to unburned areas (Figure 5).

Within BRSF, a greater number of patches and hectares of I. cylindrica occur in the areas that are also closest in distance to the paths of Hurricanes Ivan and Dennis (Figure 6). Greater blowdown occurred in the western portion of BRSF during Hurricane Ivan in 2004, and subsequently there was greater biomass removal in this area in 2005 (Figure 3). We observed a linear relationship $\left(r^{2}=0.35\right)$ between biomass removed using salvage harvesting following Hurricane Ivan in 2004 and I. cylindrica invasion in harvested stands. 
Figure 3. Map of Blackwater River State Forest depicting paths of Hurricanes Ivan and Dennis (A), biomass removal following Hurricane Ivan in 2005 (B) and Euclidian distance from Ivan overlaid on the biomass removal map (C).

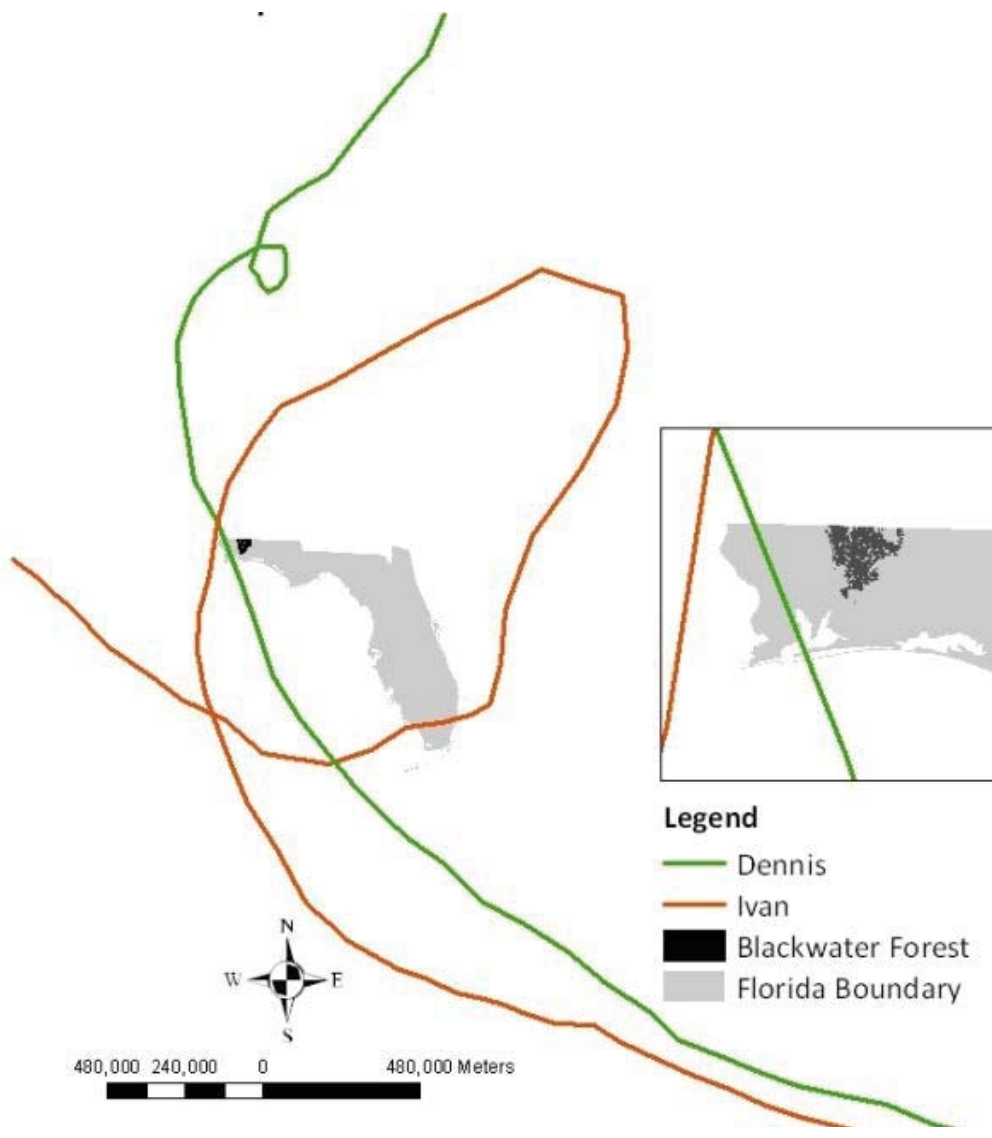

A

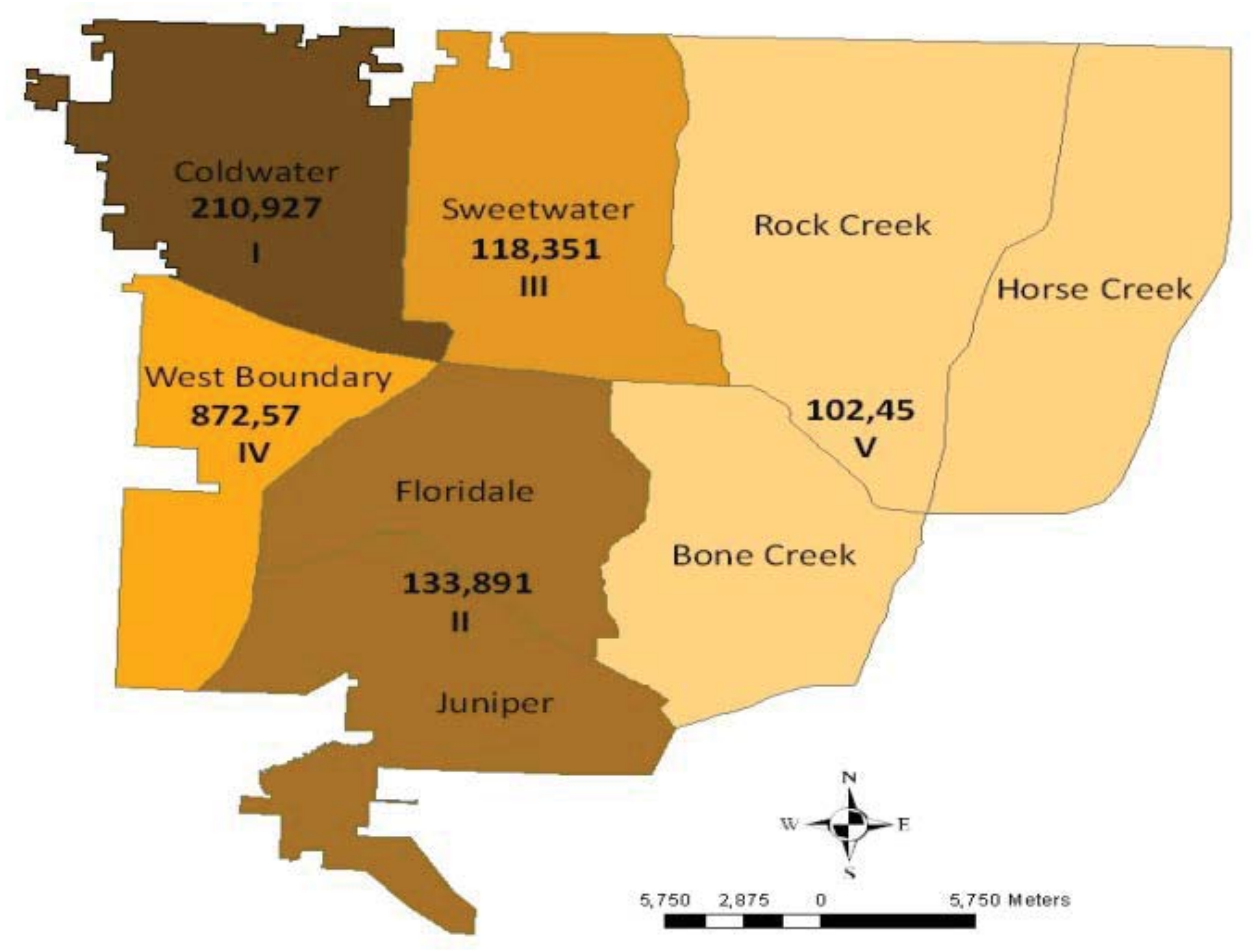

B 
Figure 3. Cont.

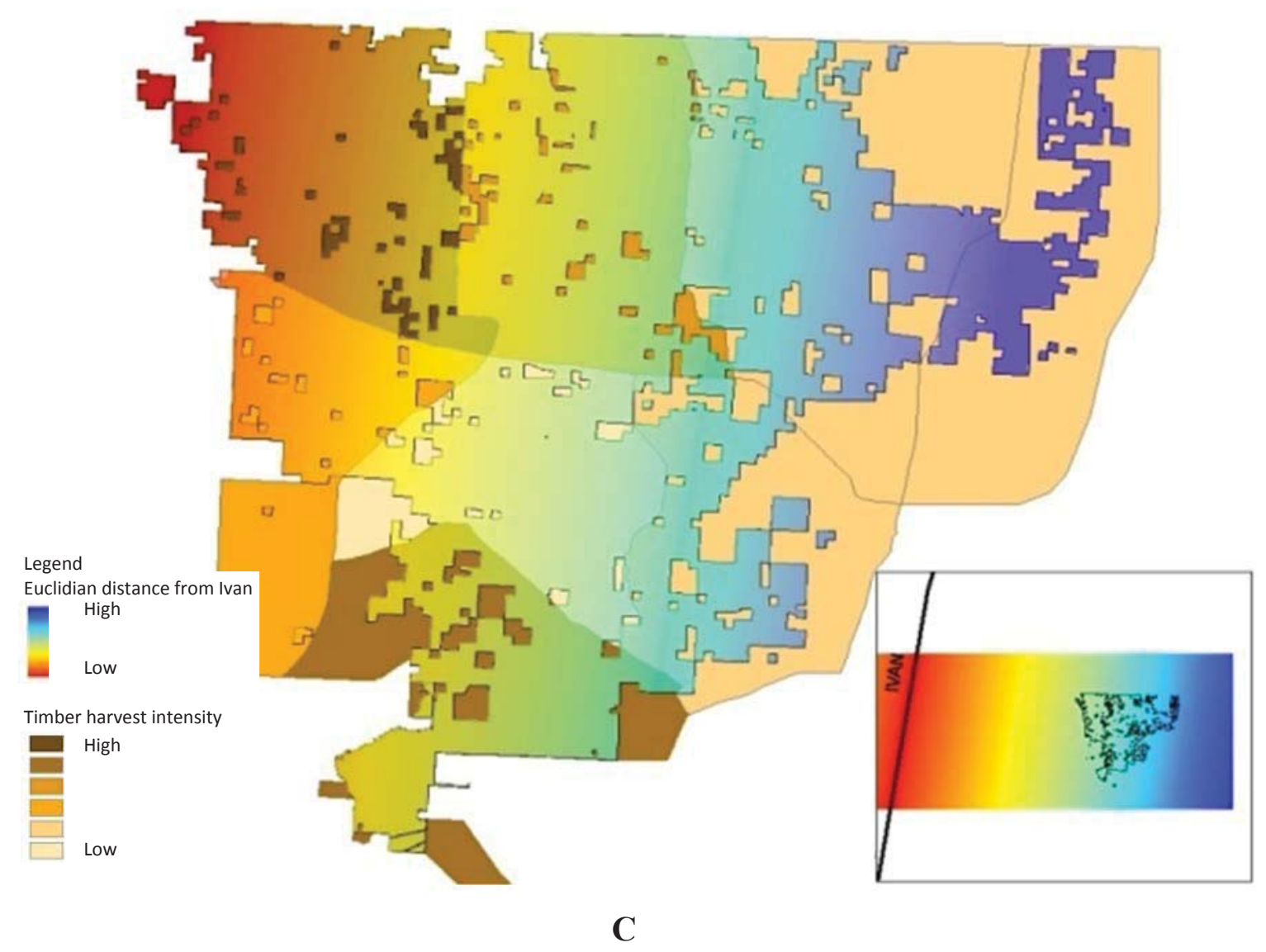


Figure 4. Map of Blackwater River State Forest showing the location (A) and size (B) of known Imperata cylindrica patches.

A.

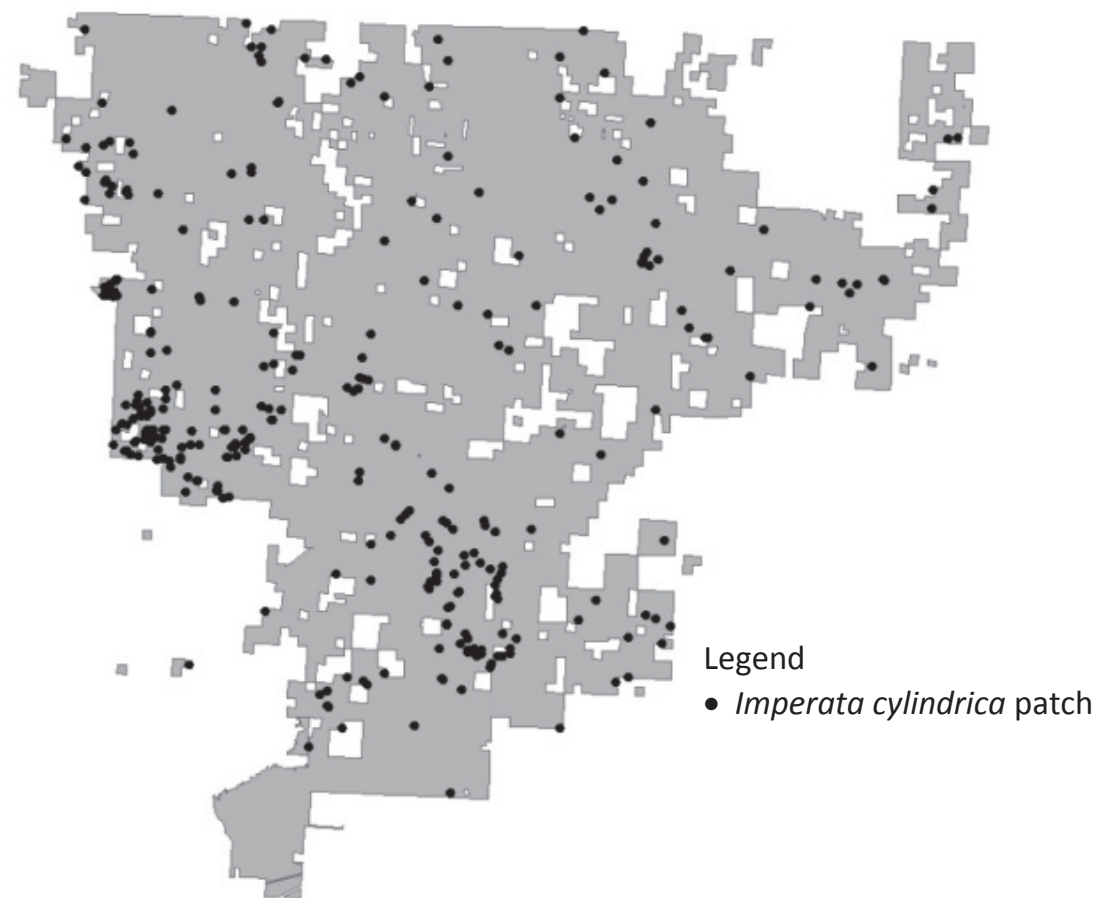

B.

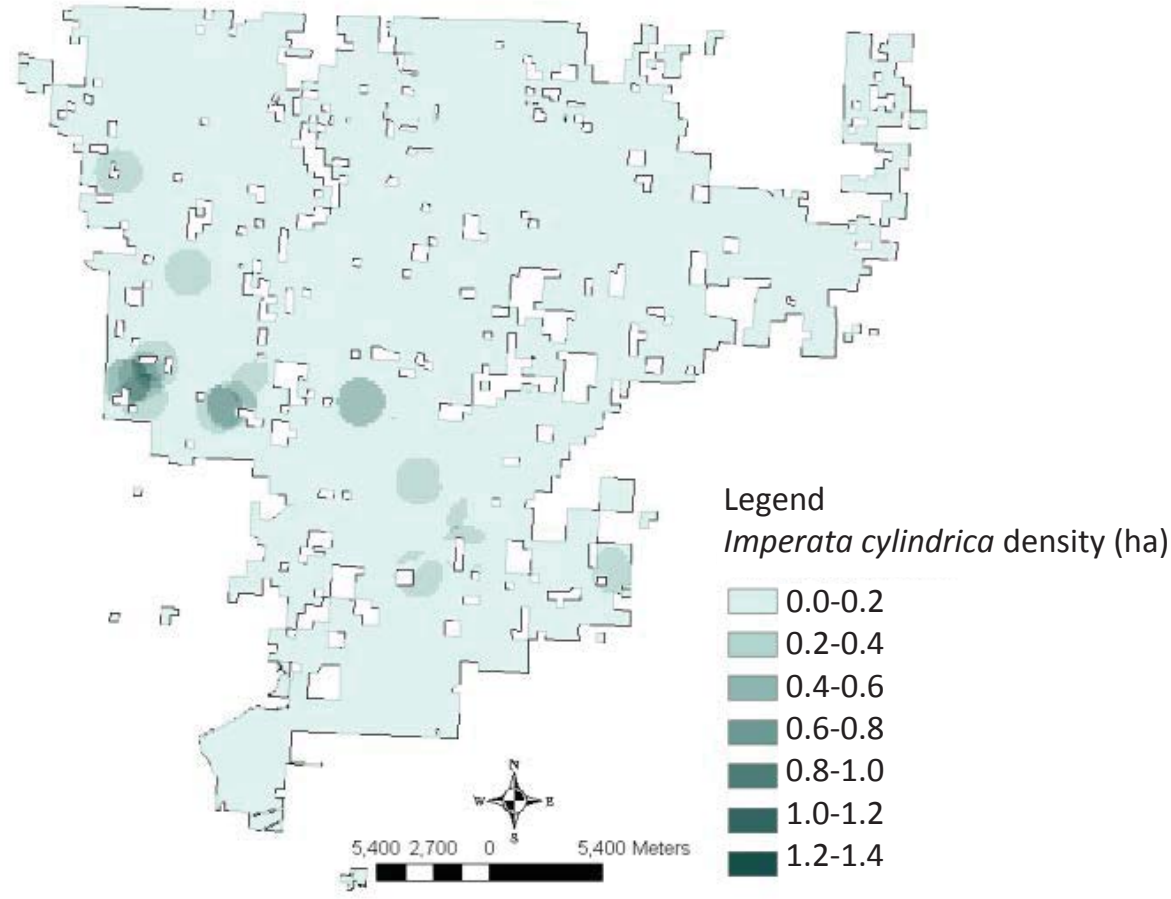


Figure 5. Relationship between Imperata cylindrica \% invasion and burn frequency in Blackwater River State Forest.

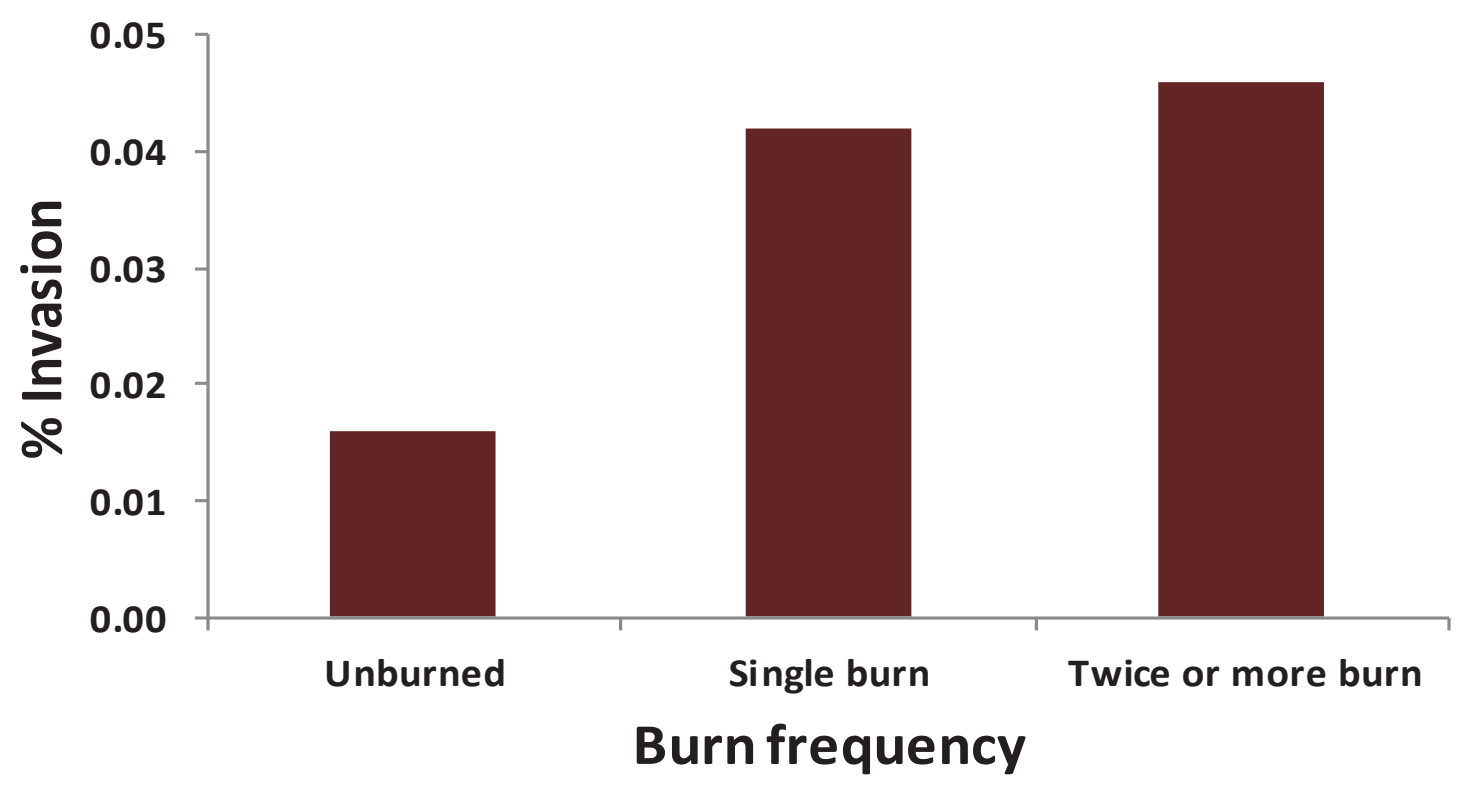

Figure 6. Overlay map of Imperata cylindrica density and Euclidian distance from hurricane Ivan in Blackwater River State Forest.

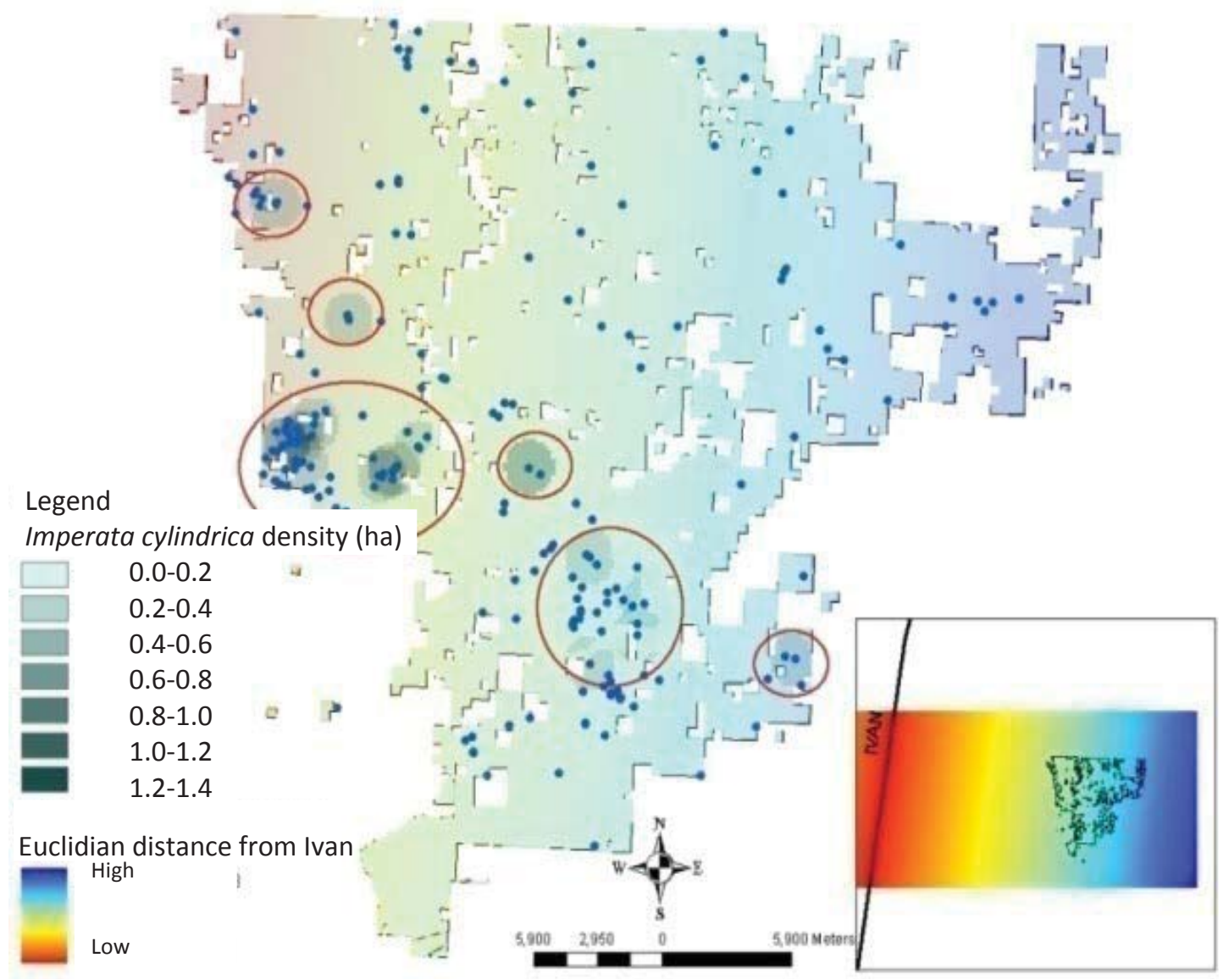


One of the reasons the I. cylindrica is thought to be so invasive is because it will become established along roads or trails where it receives full sunlight and expand from these areas into other areas that have an open canopy [14]. This is a characteristic shared by other invasive plants as well [18]. It also has the ability to tolerate low light levels and linger in small, isolated patches in undisturbed forests and expand in size once the area is disturbed [12]. Our results indicate that disturbance, both from fire and windthrow/harvesting increases the size and frequency of I. cylindrica patches across the landscape (Figures 5 and 6). This supports results from Lippincott [16] and Yager et al. [17] which observed I. cylindrica expansion following disturbance from fire in plot level experiments.

After expansion occurs following disturbance, I. cylindrica may be particularly difficult to manage in southeastern forests. Although the longleaf pine/wiregrass ecosystem relies on fire and historically burned every 1-10 years, once $I$. cylindrica invades an area it can alter the fire behavior within an ecosystem [19]. Lippincott [16] observed greater mortality of $P$. palustris saplings in areas invaded with I. cylindrica compared to areas that had native vegetation. The author reported a change in fire behavior that resulted in increased maximum temperatures which was attributed to greater fine fuels where I. cylindrica was present. Holzmueller and Jose [12] also observed increased fire intensity and $P$. palustris mortality in areas invaded with I. cylindrica in central Florida. Alteration of a fire regime is not unique to I. cylindrica. D'Antonio and Vitosek [20] reviewed multiple examples of invasive grasses that have altered the fire regimes across the globe. In general these invasions facilitated a positive feedback cycle that increased fire frequency due to increased fine fuels. A review by Brooks et al. [21] highlighted how the alteration of a fire regime by invasive plants can also have other ecosystem effects such as loss of wildlife habitat, facilitating invasion for other exotic species, and alteration watershed function.

While several studies have explored the relationship between I. cylindrica and fire, research testing I. cylindrica expansion following overstory removal from hurricane damage or salvage logging is not as available. However, several examples demonstrate that I. cylindrica control is a problem in areas where the overstory has been removed [22]. Other studies of exotic grass invasion indicate that overstory removal, particularly salvage logging following disturbance, can increase abundance of exotic species [23-25].

\section{Conclusions}

It is probable that expansion of existing populations alone cannot account for increased I. cylindrica abundance following disturbance from fire and overstory removal in BRSF. Additional spread may have come from windblown seed or propagule movement from machinery during harvest. Nevertheless there is a clear relationship between I. cylindrica abundance and disturbance at BRSF. This relationship is applicable across the southeastern United States in other areas where I. cylindrica is present, and is likely applicable in other ecosystems affected by exotic grass invasion. Treatment of $I$. cylindrica can be difficult and often requires an integrated management approach that is more than a single herbicide treatment $[15,22,26]$. This paper calls to attention the importance of monitoring and treating areas prior to disturbance, as well as, monitoring areas immediately following burning, hurricanes, or overstory removal to ensure that invasive populations do not exceed manageable levels. 


\section{Acknowledgments}

We would like to thank the Nitesh Tripathi for helping with the GIS analysis. Logistical help provided by the Florida Forest Service staff is also appreciated.

\section{Conflict of Interest}

The authors declare no conflict of interest.

\section{References}

1. MacDonald, G.E. Cogongrass: The Plant's Biology, Distribution, and Impacts in the Southeastern US. In Proceedings of the Regional Cogongrass Conference: A Cogongrass Management Guide; Loewenstein, N.J., Miller, J.H., Eds.; Alabama Cooperative Extension System, Auburn University: Mobile, AL, USA, 2007; pp. 10-23.

2. Dozier, H.; Gaffney, J.F.; McDonald, S.K.; Johnson, E.R.R.L.; Shilling, D.G. Cogongrass in the United States. History, ecology, impacts, and management. Weed Technol. 1998, 12, 737-743.

3. MacDonald, G.E. Cogongrass (Imperata cylindrica)-Biology, ecology and management. Crit. Rev. Plant Sci. 2004, 23, 367-380.

4. Lowe, S.; Browne, M.; Boudjela, S.; de Poorter, M. 100 of the World's Worst Invasive Alien Species A Selection from the Global Invasive Species Database; The Invasive Species Specialist Group (ISSG): Auckland, New Zealand, 2004; p. 12.

5. Brewer, S. Declines in plant species richness and endemic plant species in longleaf pine savannas invaded by Imperata cylindrica. Biol. Invasions 2008, 10, 1257-1264.

6. Collins, A.R.; Jose, S. Cogongrass Invasion Alters Soil Chemical Properties of Natural and Planted Forestlands. In Invasive Plants and Forest Ecosystems; Kohli, R.K., Jose, S., Batish, D., Singh, H., Eds.; CRC: Boca Raton, FL, USA, 2008.

7. Daneshgar, P.; Jose, S. Imperata cylindrica, an alien invasive grass, maintains control over nitrogen availability in an establishing pine forest. Plant Soil 2009, 320, 209-218.

8. Daneshgar, P.; Jose, S.; Ramsey, C.; Collins, A.R. Impacts of an invasive grass on the productivity of an establishing pine forest. Forest Sci. 2008, 54, 579-587.

9. Willard, T.R.; Hall, D.W.; Shilling, D.G.; Lewis, J.A.; Currey, W.L. Cogongrass (Imperata cylindrica) distribution on Florida highway rights-of-way. Weed Technol. 1990, 4, 658-660.

10. King, S.E.; Grace, J.B. The effects of gap size and disturbance type on invasion of wet pine savanna by cogongrass, Imperata cylindrica (Poaceae). Am. J. Bot. 2000, 87, 1279-1286.

11. Ayeni, A.O.; Duke, W.B. The influence of rhizome features on subsequent regenerative capacity in speargrass [Imperata cylindrica (L.) Veauv.]. Agric. Ecosyst. Environ. 1985, 13, 309-317.

12. Holzmueller, E.J.; Jose, S. Invasion success of cogongrass, an alien C4 perennial grass, in the southeastern United States: Exploration of the ecological basis. Biol. Invasions 2011, 13, 435-442.

13. Yager, L.Y.; Jones, J.; Miller, D.L. Military training and road effects on Imperata cylindrica (L.) Beauv. (Cogongrass). Southeast. Nat. 2009, 8, 695-708. 
14. Patterson, M.; Teem, D.; Faircloth, W. Mapping, Control, and Revegetation of Cogongrass infestations on Alabama Rights of Way. ALDOT Research Project 930-486; Alabama Department of Transportation and Auburn University Alabama Agricultural Experiment Station: Auburn, AL, USA, 2004.

15. Jose, S.; Cox, J.; Miller, D.L.; Shilling, D.G.; Merritt, S. Alien plant invasions: The story of cogongrass in southeastern Florida. J. For. 2002, 100, 41-44.

16. Lippincott, C.L. Effects of Imperata cylindrica (L.) Beauv. (Cogongrass) invasion on fire regime in Florida sandhill (USA). Nat. Area J. 2000, 20, 140-149.

17. Yager, L.Y.; Miller, D.L.; Jones, J. Susceptibility of longleaf pine forest associations in south Mississippi to invasion by Cogongrass [Imperata cylindrica (L.) Beauv.]. Nat. Area J. 2010, 30, 226-232.

18. Mortensen, D.A.; Rauschert, E.S.J.; Nord, A.N.; Jones, B.P. Forest roads facilitate the spread of invasive plants. Invasive Plant Sci. Manag. 2009, 2, 191-199.

19. Glitzenstein, J.S.; Platt, W.J.; Streng, D.R. Effects of fire regime and habitat on tree dynamics in north Florida longleaf pine savannas. Ecol. Monogr. 1995, 65, 441-476.

20. D'Antonio, C.M.; Vitousek, P.M. Biological invasions by exotic grasses, the grass/fire cycle, and global change. Annu. Rev. Ecol. Syst. 1992, 23, 63-87.

21. Brooks, M.L.; D’Antonio, C.M.; Richardson, D.M.; Grace, J.B.; Keeley, J.E.; Ditomaso, J.M.; Hobbs, R.J.; Pellant, M.; Pyke, D. Effects of invasive alien plants on fire regimes. BioScience 2004, 54, 677-688.

22. Ramsey, C.L.; Jose, S.; Miller, D.L.; Cox, J.; Portier, K.M.; Shilling, D.G.; Merritt, S.M. Cogongrass [Imperata cylindrica (L.) Beauv.] response to herbicide and disking on a cutover site in a mid-rotation pine plantation in Southern USA. For. Ecol. Manag. 2003, 179, 195-209.

23. Marshall, J.M.; Buckley, D.S. Effects of microsites created by selective harvesting on growth of Microstegium vimineum in a central hardwood forest. For. Sci. 2008, 54, 534-542.

24. Veldman, J.W.; Mostacedo, B.; Pena-Claros, M.; Putz, F.E. Selective logging and fire as drivers of alien grass invasion in a Bolivian tropical dry forest. For. Ecol. Manag. 2009, 258, 1643-1649.

25. Brewer, J.S.; Bertz, C.A.; Cannon, J.B.; Chesser, J.D.; Maynard, E.E.; Do natural disturbances or the forestry practices that follow them convert forests to early-successional communities? Ecol. Appl. 2012, 22, 442-458.

26. Holzmueller, E.J.; Jose, S. Response of cogongrass (Imperata cylindrica) to imazapyr herbicides on a reclaimed phosphate-mine site in central Florida, USA. Ecol. Restor. 2010, 28, 300-303.

(C) 2012 by the authors; licensee MDPI, Basel, Switzerland. This article is an open access article distributed under the terms and conditions of the Creative Commons Attribution license (http://creativecommons.org/licenses/by/3.0/). 